\title{
Crisis Communication and Crisis Management during COVID-19 ${ }^{1}$
}

\section{Key messages:}

- Most governments employed specific modes of crisis-communication vis-à-vis the COVID-19 pandemic, depending on the respective socio-political context and historical tradition;

- Crisis communication attempted to persuade the people to follow restrictive measures; the legitimation strategies employed usually appealed to authority and quasi-rational arguments; however, sometimes mythopoesis occurred.

- In times of a pandemic, denial of death does not work anymore; dread of death becomes ubiquitous.

- Four macro-frames, embedded in nativist and nationalistic rhetoric, were employed to argue for, and legitimize restrictive measures. Some heads of state (or prime ministers) instrumentalized the crisis to install ever more authoritarian practices.

1. The Dread (and/or Denial) of Death

The term 'crisis' has a consistently negative connotation in everyday life. Crises - often exaggerated by the media and politics - cause fear, panic, insecurity, and powerlessness. Dealing with great uncertainty therefore challenges all those involved during a crisis; everyone expects instructions for action, planning, explanations, and ultimately security. The sociologist Zygmunt Bauman emphasizes all these factors of insecurity in his description of crises. Uncertainty primarily promotes the emergence of fear, he claims:

'Fear' is the name that we give to our uncertainty: to our ignorance of the threat and what is to be done - what can and what can't be - to stop it in its tracks - or to fight it back if stopping it is beyond our power. (Bauman 2006, 2)

In the case of the COVID-19 crisis, uncertainty continues to play a salient role. The illness caused by the COVID-19 SARS virus was hitherto unknown. Successful treatments did not exist at first, therefore medical treatment was based on trial and error. Scientists across the globe started investigating the origin, composition, spread, and ever new mutations of the virus (see Gallagher 2020). They collaborated in numerous attempts to develop a new vaccine and to find adequate medication; ${ }^{2}$ this finally succeeded in the fall and winter of 2020 and in December 2020, the first elderly patients in the UK were vaccinated (Diaz 2020).

\footnotetext{
${ }^{1}$ I declare that there is no conflict of interest. I would like to thank Matthew Johnson and anonymous reviewers for their constructive comments, and Tim Corbett for editing my English language. Of course, I am solely responsible for the final version.

${ }^{2}$ See WHO (2020) for daily updates on the crisis and developments in countries worldwide. In this paper, due to reasons of space, I will not be able to describe individual country contexts and instead have to refer readers to this (and other similar) websites for more information.
} 
In the spring 2020, during the so-called first wave of the pandemic, however, the images repeatedly disseminated across the media of ill and dying patients in intensive care wards, specifically in Bergamo and other northern Italian cities, as well as the reported fact that there was no space left in some Italian, American, and Spanish cemeteries for the huge influx of coffins, necessarily triggered an unprecedented 'dread of death'3 (Bauman 2006, 22-24). In the summer 2020, the numbers of positive cases and deaths dropped and the severe restrictions were relaxed; many people assumed that the pandemic was almost over.

But this was not the case. The so-called second wave struck in the fall 2020; countries such as Germany and Austria registered more COVID-positive cases and deaths than in the spring. Strict lockdowns were implemented again by many governments (such as in Austria, Canada, France, the UK, Germany and Italy), even over the winter holidays and New Years' eve (Maragakis 2020) ${ }^{4}$. Moreover, horrific Islamist terror attacks occurred in France and Austria in October and November 2020 respectively; these incidents reinforced existing fears and uncertainty. The state of emergency was announced in both countries, on top of the strict lockdown due to the pandemic. As Pyszczynski et al. $(2020,5)$ rightly emphasize, 'people are living with the very real threat of death from the pandemic, combined with challenges to their worldviews, loss of jobs, impediments to career goals, and isolation from friends and family who normally validate one's significance. From a TMT [Terror Management Theory] perspective, it is currently far more difficult for virtually all of us to manage the terror of death'. ${ }^{5}$

Accordingly, death has re-emerged as part of everyday life; death can no longer be silenced even though, as Bauman claims - quoting Sigmund Freud -, our societies have tried to

\footnotetext{
${ }^{3}$ See for example EFE/Reuters (2020). For the Italian case specifically, see Pankl (2020).

${ }^{4}$ For example, the peak of the pandemic in Austria in the spring was characterized by 30 deaths (April 8, 2020). December 17, 2020 saw 218 deaths (e.g. https://www.google.com/search?q=covid+tote+in+\%C3\%B6sterreich\&oq=COVID+Tote\&aqs=chrome.3.69i57j0 i131i433j0I6.9373j1j15\&sourceid=chrome\&ie=UTF-8).Similarily, in Germany, April 15, 2020, 510 deaths were documented; December 22, 2020, however, 986 deaths (e.g., https://www.google.com/search?ei=qXHnX5SVNYubkgXV_qyIDg\&q=covid+tote+in+deutschland+2020\&oq=cov id+tote+in+Germany\&gs_Icp=CgZwc3ktYWIQARgBMgYIABAWEB4yBggAEBYQHjoFCAAQsAM6AggAOgQIABBDU LjdB1jY-gdgkpAlaAFwAHgAgAHVAYgBkQySAQYxNi4wLjGYAQCgAQGqAQdnd3Mtd2I6yAEBwAEB\&sclient=psyab) (accessed 26 December 2020). Austria which had been perceived as coping well with the pandemic in the spring was the country with the highest numbers of deaths and COVID-positive cases (in relationship to population numbers), in the fall 2020.

${ }^{5}$ Terror Management Theory (TMT) draws on Becker's ideas and provides experimental socio-psychological evidence of the many ways in which self-esteem is used as coping mechanism against anxiety. Self-esteem, TMT claims, draws on firm and positive beliefs in one's cultural worldview which can serve a death-denying function (e.g., Jost, Stern, Rule and Sterling 2017; Pyszczynski 2004; Greenberg, Solomon and Pyszczynski 2015). Although the many quantitative empirical studies in the tradition of TMT illustrate individuals' range of activities in view of danger, including during the COVID-19 crisis (e.g., Pyszczynski et al. 2020, 9), TMT and its methodology do not lend themselves to a discourse-oriented abductive approach which considers authentic and non-experimentally induced interaction such as political leaders' persuasive rhetoric to legitimize specific restrictive measures in view of the pandemic, as investigated systematically and in-depth in this paper (see also Crayne and Medeiros 2020).
} 
'eliminate death from life', to make death invisible (ibid., 39). Quite similarly, in his seminal book The Denial of Death (2020 [1973]), Ernest Becker states while drawing inter alia on Freud, Søren Kierkegaard, and Otto Rank, that '[t]he idea of death, the fear of it, haunts the human animal like nothing else; it is a mainspring of human activity - activity designed to largely avoid the fatality of death, to overcome it by denying in some way that it is the final destiny for men' ( $p$. xvii). Becker argues that human beings attempt to perceive themselves as beings of permanent value, with much 'self-esteem', in order to confront the danger of death and to make sense of their lives.

However, a pandemic such as COVID-19 changed the rules of the game; after preliminary attempts of some governments at denying the danger caused by the pandemic, in March 2020 its impact could not be ignored anymore ${ }^{6}$. According to the prominent medical journal Lancet (26 March 2020):

Over the past 2 weeks, the coronavirus disease 2019 (COVID-19) pandemic has marched relentlessly westward. On March 13, WHO said that Europe was now the centre of the pandemic. [...] However, many countries are still not following WHO's clear recommendations on containment (widespread testing, quarantine of cases, contact tracing, and social distancing) and have instead implemented haphazard measures, with some attempting only to suppress deaths by shielding the elderly and those with certain health conditions. The initial slow response in countries such as the UK, the USA, and Sweden now looks increasingly poorly judged. [...] The patchwork of harmful initial reactions from many leaders, from denial and misplaced optimism, to passive acceptance of large-scale deaths, was justified by words such as unprecedented. (The Lancet 2020)

Denial did not only occur in China, the US, Brazil, Sweden and the UK. Italy merely started implementing strict measures once Italian citizens fell ill (and not 'only' Chinese guestworkers employed in the textile industry in the North; e.g. Marin 2020). In Austria, in the first week of March, the regional government of Tyrol denied the existence of the virus in Ischgl, a well-known skiing resort; many tourists left without being informed of the danger of falling ill (Wodak 2020a, b). Although Iceland's government declared Ischgl a "Coronahotspot" on March 2, 2020, skiing lifts were shut down much later, on March 12 (Statista 2021). When confronted with such failures, politicians quickly turned blame into credit, for example when claiming to be saving the country/nation/fatherland from danger. The related argumentation was based on emphasizing one's own qualities (argumentum ad verecundiam), evoking the audience's emotions (argumentum ad populum) and the use of fallacies (e.g., false analogies; post hoc, ergo propter hoc fallacy, straw man fallacy, and so forth). Moreover, politicians trying to deny problems and avoid blame frequently employed a 'rescue narrative' in order to cast themselves as saviors (e.g., topos of savior, Wodak 2021, 76).

\footnotetext{
${ }^{6}$ I refer readers to Van Dijk (1992, 87-89); Flinders and Wood (2018, 608); Wodak (2021, 145-6) and Hansson (2015) for more details on the range of discursive strategies of denial.
} 
Mid-March 2020, most European governments decided that they could not deny the dangerous pandemic anymore and that they had to quickly cope with the crisis. Different modes of crisis communication have been adopted by government leaders to persuade people to abide by various measures to counteract the spreading of the virus, and thus to reduce fears and uncertainties. As Bauman maintains, 'all human cultures can be decoded as ingenious contraptions calculated to make life with the awareness of mortality liveable' (ibid., 31). Yet, some governments have instrumentalized the pandemic for their authoritarian aims. For example, security measures have been implemented which have had a huge impact on citizens' fundamental rights. Subsequently, many debates have emerged challenging such sweeping measures and appealing for more transparency in governmental decision-making procedures: Were the measures indeed necessary? How were they officially legitimized? By whom?

It is, of course, impossible at present to take stock of the different types of crisis management and crisis communication as well as counter-discourses because the crisis is not over yet. Thus, in this paper, I can only present interim findings - findings which cover a clearly defined discourse strand, i.e. governmental discourses during the global lockdown from March 2020 to June 2020 (as discussed in section 3). By analyzing a sample of important speeches and press conferences by European government leaders (all performing as the 'face of crisis management') in Austria, Germany, France, Hungary, and Sweden, it is possible to deconstruct measures and procedures deemed adequate for coping with this pandemic ${ }^{7}$. Due to limitations of space, however, I have to omit oppositional voices to governments' decisions and COVID-19 deniers in government, i.e. those leaders who denied and trivialized the danger caused by the pandemic, such as Donald Trump, Jair Bolsanaro, and - at least initially - Boris Johnson. ${ }^{8}$

In this paper, I focus on four frames as the result of an abductive and comparative discourse-historical analysis, each of which is strategically employed - in respect to different socio-political contexts - to mitigate the 'dread of death': a 'religious frame', a 'dialogic frame', a frame emphasizing 'trust', and a frame of 'leading a war' (section 5). Importantly, these frames are discursively legitimized in significantly different ways (section 3). Due to

\footnotetext{
${ }^{7}$ The chosen countries contrast richer and poorer countries (along the North/South divide in the European Union), Western and Eastern European countries, and Sweden as a country which chose a very different way of dealing with the crisis. Here, I focus only on five EU member states due to limitations of space, although the data set also includes Poland, Greece, Italy and New Zealand. I mention some examples of the latter in passing. Of course, the selection nevertheless remains subjective. Moreover, I have to neglect details of the sociopolitical and historical contexts, of the looming economic crisis all of which necessarily trigger a huge dilemma: to save "the people" or to save "the economy"? Fear of death is reinforced by fear of unemployment and vice versa (e.g., Schmidinger and Weidenholzer 2020). Obviously, more deaths occurred if the health system had suffered significant cuts due to austerity politics like in Italy, Spain, Portugal, France and the UK.

${ }^{8}$ See, for example, Stern (2020); Khoo and Schimpfössl (2020); Novy and Winckler (2020) for analyses of the COVID-19 management in the US, the UK, and Brazil.
} 
the fact that threatening economic and political crises $^{9}$ trigger a patriotic nationalism, a unification of 'us' against 'them' which even transcends traditional cleavages of left and right (section 4), it is not surprising that this has also been the case with COVID-19. Even the Schengen Area was suddenly suspended in response (in order to 'keep the virus out') and borders were closed.

\section{Crisis and the Emergence of Fear}

Bauman analyzes the pervasiveness and consequences of fear in contemporary Western life, drawing on his earlier work Liquid Modernity (2000). Liquid society per se is characterized by instability and ambiguity and by the fragmentation of life and experience under conditions of rapid change. It is thus a society where uncertainty, flux, change, conflict, and revolution are the permanent conditions of everyday life. Bauman argues that this situation is neither modern or postmodern, but rather that traditional categories of existence are disintegrating, overlapping, and remixing. There seem to be no more distinctions between global and local anymore, or between work and non-work, between public and private, between conservative and progressive, or between mediated and non-mediated experiences. Hence, life in liquid modernity is characterized by endemic uncertainty, which - during a pandemic - is, of course, reinforced and mobilized.

In his research, Bauman analyzes the consequences for our ability to engage in meaningful social action and to produce a viable future in spite of such fear and uncertainty. Liquid fear is a derivative fear resulting from the interiorization of 'a vision of the world that includes insecurity and vulnerability', which 'even in the absence of a genuine threat' (p. 3) will produce a reaction appropriate to the presence of real danger. Derivative fear is used by the state to assure citizens' obedience in exchange for supposed protection against threats to their existence.

Such derivative fear - as will be illustrated in the next sections - is instrumentalized by governments in various ways in order to persuade people to comply with restrictive measures in view of the pandemic. For example, religionization of politics and oversimplification of problems (by arguing away their root causes and consequences) offer, as Bauman maintains, 'a life free from doubt, and absolution from the vexing and harrowing necessity of making choices and taking responsibility' (p. 116).

Governments frequently legitimize their policy proposals with an appeal to the necessities of security. Such arguments became eminent after the end of the Cold War in 1989 and were forcefully reinvigorated after 9/11, in the course of the refugee movement in 2015/16 (usually referred to as the 'refugee crisis'), and when confronting the terrorist activities engaged in by ISIS and extreme-right terrorists. Each crisis contributes to both new and old threat scenarios, as could be observed with respect to the financial crisis, the Euro crisis, the

\footnotetext{
${ }^{9}$ See Pyszczynski (2004); Triandafyllidou et al. (2009); De Rycker and Mohd Don (2013); Neüff (2018) for examples of nationalizing tendencies in times of crises.
} 
SARS crisis, and the so-called 'refugee crisis' ${ }^{10}$. Not surprisingly, the COVID-19 pandemic also follows this pattern.

\section{Discourse, Frame, and Legitimation}

\subsection{The Discourse-Historical Approach}

The Discourse-Historical Approach (DHA) allows for a systematic relating of macro- and mezzolevels of contextualization to the micro-level analyses of texts. Such analyses consist primarily of two levels, the 'entry-level analysis' focusing on the thematic dimension of texts (the 'frames') and the 'in-depth analysis' which deconstructs the coherence and cohesion of texts in detail. The general aim of the entry-level thematic analysis is to map out the contents of analyzed texts and, through that mapping, to assign them to particular discourses (see Wodak 2020c, 2021 for more details).

The key analytical categories of thematic analyses are discourse topics, which, 'conceptually, summarize the text, and specify its most important information' (van Dijk 1991, 113). These discourse topics characterize relevant frames and interpretation frameworks. The in-depth analysis, on the other hand, is informed by the research questions. The in-depth analysis consists of the identification of the genre (e.g., TV interview, policy paper, election poster, political speech, or homepage), analysis of the macro-structure of the respective text, the strategies of identity construction and of the argumentation schemes, as well as of other means of linguistic realization it uses.

The DHA views discourse as a set of 'context-dependent semiotic practices' which are 'socially constituted and socially constitutive', 'related to a macro-topic' and characterized by a 'pluriperspective', i.e., linked to argumentation (Reisigl and Wodak 2009, 89). This approach focuses on texts - be they audio, spoken, visual, and/or written - as they relate to structured knowledge (discourses), are realized in specific genres, and must be viewed in terms of their situatedness. That is, many texts cannot be fully understood without considering different layers of context (e.g., four-level model of context; Reisigl and Wodak 2001, $40 \mathrm{ff}$.). In this paper, I investigate a specific discourse strand, from the beginning of the first lockdown in March 2020 through to the relaxation of restrictive measures in June 2020.

Discourse strands are defined as topical threads within discourses (Rheindorf 2019, 210-11). Ideally, such strands can be investigated through subsets of data within a corpus representing the discourse they are part of. In brief, discourse strands are distinguished by topical continuity and boundedness, strong intertextual links (often explicit) and temporal proximity between its textual elements, an often-limited group of social actors, and high keyness values (for distinctive elements in the subcorpus, using the total corpus as reference). In many instances, an initiating event or events can be identified as triggering

10 See, for example, Stråth and Wodak (2009); Angouri and Wodak (2014); Powers and Xiao (2008); Huang and Holmgreen (2020). 
debates that feed into such strands (for example, the official announcement of the lockdown in March 2020; Rheindorf 2018, 182-83). This delimitation in turn allows for a focused contextualization, making 'discourse strand' a useful perspective in tracing the dynamics of discursive shifts, e.g. peaks, changes, and normalizations.

In sum, the DHA focuses on the ways in which power-dependent semiotic means are used to construct positive self- and negative other-presentations (US and THEM, in our case the contrast between successful coping with the virus and failures). A thorough DHA ideally follows an eight-stage program. Typically, the eight steps are implemented recursively (see Wodak 2020c for more details). As the research presented here consists of a qualitative comparative study, the first five steps are conducted in a recursive manner:

1. Activation and consultation of preceding theoretical knowledge (i.e., recollection, reading, and discussion of previous research).

2. Systematic collection of data and context information (depending on the research question, various discourses and discursive events, social fields as well as actors, semiotic media, genres, and texts are focused on).

3. Selection and preparation of data for the specific analyses (selection and downsizing of data according to relevant criteria, transcription of tape recordings, etc.).

4. Specification of the research question/s and formulation of assumptions (on the basis of a literature review and a first skimming of the data).

5. Qualitative pilot analysis, including a context analysis, macro-analysis, and micro-analysis (allows testing categories and first assumptions as well as the further specification of assumptions; see example below).

6. Detailed case studies (of a whole range of data, primarily qualitative, but in part also quantitative).

7. Formulation of critique (interpretation of results, considering the knowledge of the relevant context, and referring to the three dimensions of critique).

8. Practical application of analytical results (if possible, the results might be applied or proposed for practical application aiming at having social impact and changing discourses).

\section{2. $\quad$ Framing and Legitimizing}

In this analysis, I draw on Robert Entman's approach to 'framing' (who in turn adopts Erving Goffman's salient theory; e.g., van Dijk 2020). As Entman explains, to frame 'is to select some aspects of perceived reality and make them more salient in the communicating' text. According to Entman, framing 'plays a major role in the exertion of political power and the frame in a news text is really the imprint of power' $(1993,52)$.

Historically speaking, Goffman's interest in frames and framing coincides with frame analysis in other disciplines, especially in linguistics and Artificial Intelligence (van Dijk 2020, 35-36). For example, Fillmore (1976) already published his seminal paper 'Frame Semantics 
and the Nature of Language' two years after Goffman's work, which led to a broad research paradigm ('Frame Semantics') focusing on frames as a basis especially for the study of word meanings, and later more generally research in the field of cognitive linguistics. Fillmore was interested in framing as 'the appeal, in perceiving, thinking, and communicating, to structured ways of interpreting experiences.' Thus, understanding words does not require traditionally conceived word meanings, but a more complete understanding of the multimodal experience of the situations or events these words refer to. In other words, frames in this case represent socially shared fragments of world knowledge, each organized in specific ways. Fillmore goes beyond the study of isolated word meanings and advocates a study of communication and messages. Interestingly, Fillmore not only stresses notions such as frames, as relevant for discourse, but the notion of context, too.

In the discourse-historical analysis below, I combine legitimation analysis with frame analysis (see, for example, Wodak 2018, 2019b, 2020a). Frames serve as 'interpretation frameworks', as worldviews, or - speaking in the terminology of Terror Management Theory - as 'cultural worldviews'. 'Interpretation framework' (Deutungsrahmen) is the label for 'frame' used in the paradigm of sociology of knowledge (e.g. Gotsbacher 1999). The function of 'interpretation frameworks' for text comprehension is to convey elements of meaning that can be invoked by speakers and writers as self-evident (e.g., Cicourel 1975). Such presuppositions and expectations are picked up by the respective audience, through which the statements made are invested with their complete meaning (i.e. 'dialogicity'; Bakhtin1982). These elements consist on the one hand of definitions of the identities of the speakers, which are indexed and assigned through mechanisms of negotiating social identities and relationships. On the other hand, these are definitions of the context and the implied social knowledge.

The epistemic knowledge that is shared amongst a community allows the audience to categorize the isolated text components in such a manner that unspoken or missing elements can be added while polysemous or contradictory statements can be understood according to the broader context. As mentioned above, the entry-level thematic analysis allows for those discourse topics to be detected which condense the respective frame; in our case, the strategic choice of a specific mode of governmental crisis communication to cope with the dread of death triggered by the pandemic. Obviously, governments have to legitimize their choice of frames. Given its socio-political nature, it follows that legitimation routinely draws on recurring argumentation schemes in order to persuade the public of the acceptability or necessity of a specific action or policy.

Van Leeuwen and Wodak (1999) introduced a framework for analyzing the language of legitimation with four major categories: authorization, moral evaluation, rationalization, and mythopoesis. Legitimation qua authorization depends on reference to personal, impersonal, expert, or role model authority, but may also appeal to custom in the form of tradition or 
conformity. Legitimation qua moralization is based on abstract moral values (religious, human rights, justice, culture, and so forth), straightforwardly evaluative claims, or analogy to assumedly established moral cases. Legitimation through rationalization references either the utility of the social practice or some part of it (i.e. instrumental rationalization by way of goals, means, or outcomes) or to assumed 'facts of life' (i.e. theoretical rationalization by way of definition, explanation, or prediction). Rationalization may be established as 'common sense' or by experts in the domains of knowledge used for legitimation, e.g. economics, biology, or technology. In legitimation through mythopoesis, the proponents of the policy in question will rely on telling stories that may serve as exemplars or cautionary tales.

These main types involve a number of sub-types and are also frequently connected. Thus, to understand the specific dynamics of legitimation in particular contexts, such as the financial crisis of 2008 or the COVID-19 pandemic, it is important to focus on the typical patterns and characteristics of these discursive strategies in context. Legitimation strategies are necessarily linked to specific content-related argumentation schemes which serve to substantiate specific decisions in retroductable, frequently common-sense ways (Rheindorf and Wodak 2020; Wodak 2018). As elaborated by Wodak $(2021,84)$, legitimation can also involve problem-denial, combined with a counter-attack, accompanied with negative Otherpresentation, that is, attacking the (sometimes only alleged) accusation and accuser (see section 4). In this case, the argumentation is frequently based on discrediting the opponent (argumentum ad hominem), on threatening the opponent (argumentum ad baculum) or on an alternative claim, applied to shift blame. Moreover, relativizing and trivializing strategies occur, frequently by using (fallacious) comparisons or strategies of equation: 'The 'normal' flu is also dangerous'.

\section{COVID-19 and Renationalizing Tendencies}

Analogies and comparisons, arguments using statistics, ratings and numbers, and persuasive rhetoric appealing to citizens to abide by regulations and measures were salient strategies adopted during the lockdown months in most countries where government leaders took the danger posed by the COVID virus seriously. A re/nationalizing tendency became apparent throughout, specifically when attempting to persuade citizens to follow the rules of the respective country. We are therefore confronted with national biopolitics and body politics (Musolff 2010; Wodak 2019a, 2019b, 2021; Boin, Lodge and Luesink 2020).

For example, in Austria, no one could doubt who should ultimately be considered the 'savior of the nation', a wise and strict 'father' who cares for all 'real' Austrians and sets rules accordingly, to put it in terms of linguist George Lakoff and his metaphor of the 'nation as a family'. Fear and renunciation, so the promise, are followed by hope and salvation (Lakoff 2004). Overall, the often-quoted nationalistic 'closing of ranks' has a calming effect. Chancellor Sebastian Kurz emphasized repeatedly, for example in the ZIB Spezial (the main 
news channel) on 30 March 2020, 'I have firm faith in our Austria'. Moreover, in parliament on 3 April 2020, Kurz was completely convinced that Austria or 'Team Austria' would successfully overcome the crisis - better, in fact, then other countries. A nationalist competition seemed to be the order of the day:

I guarantee you that Austria will survive this crisis: Austria will get through this crisis better than other countries, Austria will get out of this crisis faster than other countries, but only if we stand together and if we do one thing: persevere.

At around 6 pm every day, 'I am from Austria', a famous pop song from the 1970s, was played on the streets by the police while some people waved red-white-red flags and the critical workers received much-deserved applause from the windows. This was an obvious return of the so-called 'banal', everyday nationalism (Billig 1995; Lehner and Wodak 2020; Corbett 2020). The many interviews and press conferences left no doubt that 'we as the Republic of Austria were one of the first countries in Europe to act with restrictive measures by reducing to emergency operation' (Kurz, ZIB Spezial, 30 March 2020).

Kurz also increasingly emphasized that there was no alternative to the governmental measures; the so-called TINA-argument ('there is no alternative') was employed as rationalization legitimation. Decisions were thus essentialized:

'We are doing the right thing'; 'We are completely convinced that we are doing the right thing'; 'The measures we are taking are the right ones' (ZIB Spezial, 30 March 2020). 'All studies prove: If we had not taken these steps, there would be a massive spread in Austria with up to a hundred thousand dead' (Kurz, ZIB II, 6 April 2020).

Praise was expressed, according to Lakoff's approach, toward the 'good and well-behaving children' of the Austrian family: 'We are impressed by what you are achieving', 'Hang in there', and, because the crisis could be compared to a really stressful and challenging sporting effort: 'This is a marathon' (Kurz, ZIB Spezial, 20 March 2020).

The Italian Prime Minister Guiseppe Conte also weathered the huge crisis by creating reassurance, introducing severe restrictions, and unifying the people with much empathy and some but not exaggerated pathos, for example by evoking Winston Churchill's famous 'Call to War'. Conte became the 'face' of the crisis, always televised sitting alone at his desk and addressing the people. He imposed a lockdown, at first localized, on 22 February, which he extended to the entire peninsula on 9 March. On that occasion, Conte stated that 'there is no more time - our future is in our hands', thus employing the topos of urgency and the TINA-argument, and simultaneously appealing to the Italian people with the inclusive pronouns 'our' and 'we'. Rationalization legitimation coupled with legitimation qua expert authority was here employed. Conte argued that everybody - 'we' - would have to change their - 'our' - lifestyle, promising state support for everybody and concluding on the positive note that there would be an end to the crisis (pronouns indicating unity are marked in bold): 
The figures show we are experiencing a serious increase in infections, an increase in people hospitalized in intensive care - and an increase, unfortunately, in deaths. We need to change our lifestyle. We need to change it now. T[...] The health emergency, as we foresaw, is turning into a full economic emergency, but I want to say to all of you that the state is here, the state is present. The government will take extraordinary measures that will allow us to stand up again and restart as soon as possible. (ITV News 2020)

In the face of horrific daily pictures of the many dead, the strategies of unification and the vision of a 'normal' future proved enough to confront the dread of death. Conte's slogan 'Today we don't hug each other, only to hug each other all the more tomorrow' became the hegemonic, patriotic imaginary for many (Braun 2020), indicating legitimation qua mythopoesis. Of course, the 'Italian success story' depends heavily on how the looming economic crisis will be coped with - and this remains unpredictable (Lazar 2020).

National identity politics necessarily imply positive self and negative other presentations. From this perspective, events, statistics, and technical discourses provide resources for the context within which governments draw on binaries such as good and bad people, perpetrators and victims, experts and lay persons, healthy and sick people, old and young people, people who follow the rules and people who do not. Moreover, media panic produces and reproduces strategies of blame and denial which lead to narratives of decline, helplessness, rise or success, power or control, as well as a vehement scapegoating rhetoric (Wodak 2021). These scapegoats, according to media constructions and the proposals of some politicians, have to be punished and suffer the consequences of their actions.

During the first months of the COVID crisis, the scapegoats varied, ranging from Trump's label 'the Chinese virus' to the Austrian government's 'Croatian virus' in reference to the people who had spent their holidays outside of Austria, in Croatia, in spite of patriotic propaganda urging everybody to remain in Austria for their holidays in order to boost the Austrian economy. Moreover, since the end of the lockdown in May 2020, we have been confronted with counter-discourses spreading conspiracy theories about the origins of the virus. Bill Gates, George Soros, virologists, pharma businesses, politicians, the media, and so forth are allegedly to blame for the pandemic (e.g., Spring and Wendling 2020), thus reinforcing a nativist body-politic. Large protests and demonstrations against the regulations, the experts, the government, i.e. the elites have taken place in Berlin and other capital cities (e.g., BBC News 2020). These protests were started by worried and angry citizens and were subsequently exploited by far-right and extreme-right parties and movements, all of whom were applying their traditional protest patterns.

\section{Four Frames and their Legitimation}

\subsection{The Religious Frame - Legitimation Qua Moralization}

In the Austrian hegemonic discourse, the Catholic Easter festival became a turning point during the COVID crisis and lent itself to the construction of a religious frame. The 
employment of a natural disaster metaphor served to construct dystopian scenarios and to add a haunting tune full of pathos for suffering and death:

This crisis will mean illness, suffering, and for some people death' (Kurz, ZIB Spezial 14 March 2020). 'The virus threatens the most important thing that exists for us, namely our health' (Kurz, ZIB Spezial 18 March 2020). 'This is the biggest crisis since World War Two'. 'Many people cannot imagine what is coming in a few weeks. This is the calm before the storm'. 'We will soon have a situation in Austria, too, that everybody will know somebody who has died of Corona' (Kurz, ZIB Spezial, 30 March 2020).

Should the virus be defeated (here employing a war metaphor), Kurz promised a 'resurrection' after Easter, thus using a Catholic frame, an allusion to the redemption narrative:

'Easter week will be a decisive week for us. It will be a week that will determine whether the resurrection after Easter that we all wish for can take place'. (Kurz, ZIB Spezial, 6 April 2020).

The religious frame offers consolation in times of dreading death. As Bauman (2006, 30) maintains: 'Death is the 'unknown' incarnate; and among all other 'unknowns' it is the only one fully and truly unknowable. Whatever we have done to prepare for death, death finds us unprepared'. Everybody is afraid of death, Bauman continues. During a pandemic, therefore, a time when many people die, people necessarily become more aware of death, one cannot deny its presence. Accordingly, 'the prospect of eternity' is a 'source of perpetual joy for the good and diligent' (Bauman 2006, 32). This frame lent itself ideally to cope with the uncertainty caused by the pandemic and the inherent fear of death and thus morally legitimized even the most restrictive measures.

In addition, the official rhetoric promised a victory over the virus after a long and painful ordeal and much suffering and depicted a future full of hope, as stated in an 'open letter of the Federal Chancellor before Easter' (11 April 2020, quoted from vienna.at 2020). Here, Austrian citizens were confronted with legitimation qua mythopoesis:

Our Easter is taking place under special circumstances this year. [...] The measures being taken demanded a lot from us, but were necessary to prevent the worst. Four out of five people infected with Corona have no symptoms and therefore do not know that they are ill. However, they can still infect other people, for whom the disease is potentially fatal. This is one reason why the virus is so dangerous for our society. [...] Next year at Easter, we want to be able to look back together and say, 'good that we defeated the Coronavirus'.

A similar religious frame to cope with the fear of uncertainty and death was employed by the conservative Greek government. For example, Prime Minister Kyriakos Mitsokakis addressed the Greek people before Easter in a speech (Mitsotakis 2020) full of religious concepts, following his main argument formulated in analogy to the Passion of Jesus, namely that people first have to suffer and make large sacrifices in order to be saved and resurrected in a 'victory of life over death'. Aside from this analogy, the conceptual metaphor of a natural catastrophe (a storm) was employed, a storm which forces everybody to stay at home and wait until it has passed. Such metaphors imply that human beings are powerless but also innocent; they cannot prevent the storm, they have to be patient. 
I indicate the religiously connoted wording in bold in the extract below; this semantic field explicitly indicates legitimation via moralization and authorization. The argumentation scheme is easy to deconstruct: If we remain humble, faithful, suffer patiently, and do not lose hope, then our sacrifices will be rewarded.

I shall conclude with the following thoughts:

In our previous communication, I stressed that in the fight against Covid-19, April would be the most critical month. Today I am telling you that this is the most critical week! A true Holy Week, reflecting our Passions and sacrifices this year, for us to overcome the Golgotha of the pandemic and achieve the Resurrection. We will remember this Easter as the Easter of Love. But also as the Easter of Responsibility. We will be celebrating apart from our loved ones. And perhaps far away from our places of origin. And with no church worship. I know it is very difficult. It is not our faith that is at stake, but the health of the faithful. In this way, however, we will uphold the true message of this great celebration: the victory of life over death. Thus, this Holy Week acquires a special spirituality. [...] So let us stay home, in order for us to meet again, healthy and strong, when the storm passes. If we stay at home, we will emerge as winners. Because victory is only separated from disaster by a thread; if we do not follow the advice of the experts to the end, we may tear apart all we have accomplished. (Mitsotakis 2020)

The combination of religious framing with strict measures during the lockdown and appeals to responsibility proved effective in managing the COVID crisis in Greece. In comparison to other countries that rely heavily on tourism, the death toll remained low in relation to population numbers (WKO 2021); the strict measures were relaxed very slowly, in contrast, for example, to Austria, where a speedy relaxation (pushed for by businesses and the large and powerful tourism lobbies) have led to a shockingly fast rise in the number of positive cases during the summer and autumn of 2020.

\subsection{A Dialogic Frame - Legitimation Qua Rationalization and Authorization}

Germany (and inter alia New Zealand) engaged in a quasi-dialogue with their citizens. One could view Chancellor Angela Merkel as a caring mother attempting to explain the complexity and dilemmas of the crisis step by step. Merkel addressed Germany's citizens only a few times via TV and press conferences, with medical experts and virologists instead taking the stage and becoming the 'face' of the crisis.

Every day, the renowned virologist Christian Drosten, Director of the Institute for Virology at the Charité Hospital in Berlin, held highly authoritative lectures on YouTube, which were viewed by millions, including outside of Germany (Schumann \& Simmank 2020). The decisionmaking of the German government was made transparent. Merkel used little pathos and instead justified the restrictive measures, which were usually conveyed in a list, with scientific arguments, thus via rationalization legitimation. Importantly, she appealed to everybody to participate in the effort to contain the virus. It was, she said, everybody's responsibility to support this effort, without invoking threat scenarios and, therefore, without triggering fear.

On the contrary, through her calm attitude and rather technical discourse, Merkel was able to provide much reassurance and trust in the government and the experts (legitimation qua authorization and rationalization); she explained the measures in detail and emphasized the 
complexity of the crisis. However, she also foregrounded a nation-unifying rhetoric, in the sense of 'we are all in the same boat', with much empathy. Importantly, she maintained that she was fully aware of the fact that these measures were undemocratic and that some of these measures actually violated fundamental rights: They were 'an imposition on democracy'. She stated that she had hardly ever had to make such a difficult decision as this curtailment of personal liberties (BR24 2020).

Merkel talked to the people with much respect, establishing a quasi-egalitarian relationship, always providing a more holistic orientation at the beginning of her presentations (Merkel 2020), before listing new rules explicitly and clearly. Before doing so, she thanked the government and the regional governors for reaching such a unanimous decision, and she thanked the citizens, too. This was also the point where she emphasized her own feelings: Merkel was moved and happy that 'we can save elderly people' (speech from 22 March 2020). In the extracts of this speech, I mark all lexical items and phrases employed to establish a relationship with the audience ('the people') in bold. Items expressing emotions are printed in italics. Finally, speech-acts announcing and explaining the measures are underlined.

Before I explain in detail the expanded guidelines agreed upon today by the federal and regional governments, I would like to directly address all of those who are currently adhering to the necessary behavioral regulations. I thank you. I know that these mean relinquishments and sacrifices, both economically and personally, with stores having to close, not being able to simply go out in public anymore and, what is perhaps more painful, not being able to meet one's grandparents or friends. We will all have to do without these things for a while. I am very moved that so many people have adhered to these behavioral regulations. We have thus demonstrated our commitment to the elderly and those with prior illnesses, for whom the virus is most dangerous. Put simply: We are thereby saving lives.

She concluded on a typically positive note, conveying the hope that everybody would be able to survive the crisis if they behaved rationally and followed the necessary measures together. No threats were uttered, fear was not evoked:

It is greatly encouraging to see today how millions and countless more millions of people are very pragmatically adhering to these relinquishments out of communal spirit and caring for endangered groups. I am convinced that this communal spirit, this 'standing up for each other', will bring us all through this difficult time together.

Like in most countries where governments took the COVID crisis seriously, Merkel also received much positive feedback. Her popularity swiftly rose in all opinion polls to 64 percent, with many commentators even speculating about the possibility of a fifth period of office for Merkel (Merkur.de). Indeed, on the basis of an in-depth abductive and qualitative study, Hattke and Martin $(2020,2)$ claim that 'Germany [is] a critical and politically important case in point to counter the calls for more centralized and hierarchical approaches to the COVID19 pandemic'. Coordination, collaboration, and cooperation (and emerging dilemmas), they maintain, were adequately solved by collective action (Hattke and Martin 2020, 9-10) and 'for tackling complex crises that resemble wicked problems that are characterized by high degrees 
of uncertainty and ambiguity and the absence of evidence-based solutions ' (Hattke and Martin 2020, 13).

\subsection{Sweden's 'Uniqueness' - Establishing and Maintaining Trust}

The 'Swedish way' differed from that of all other liberal democratic countries: Sweden never introduced a complete lockdown, thus schools, shops, bars, and restaurants remained open. A few rules were introduced (for example, gatherings were limited to 50 people) but mostly, the government decided to propose recommendations that experts, and specifically Sweden's state epidemiologist Anders Tegnell, believed to be relevant and effective in order to contain the spread of the virus. Rarely did the government turn to and appeal to the people, though virtually every Swede listened to Tegnell's daily updates on TV and radio.

The people seemed to have trusted the government in spite of an extremely high death rate early on (in comparison, for example, to other Scandinavian countries), while the government trusted people's responsibility in getting on with their daily lives (legitimation via rationalization and moralization). As politicians in other countries were challenged with questions about the Swedish way and why they would not follow this example, they were quickly to reply that Sweden is very different, geographically and politically. For example, Sweden is less densely populated. Critics emphasized that Sweden had not protected their elderly people adequately in order to maintain 'normality'.

As Simon $(2020,49)$ notes in an in-depth study comparing crisis management in the Nordic countries, some political speeches also displayed the attributes of attempting to promote and export the 'Swedish way'; for example, a speech by Lena Hallengren (2020), Minister of Health and Social Affairs, to the WHO:

There has been some interest internationally in our approach to combat the virus. [...] But in order to understand our approach, it helps to be aware of some fundamental characteristics of Swedish society. Our welfare state is universal, including the health care system. It is publicly funded and accessible to all. [...] There is a tradition of mutual trust between public authorities and citizens. People trust and follow the recommendations of the authorities to a large extent. The Swedish Government has, from the start of the outbreak, applied a 'wholeof-Government' approach. [..] Our measures aim to save lives and slow down the outbreak. We've carried out a number of reforms to strengthen our health care system so that our doctors and nurses can cope with the extraordinary challenge that COVID-19 poses.

Recent research (Pierre 2020; Helsingen et al 2020; Bergenfalk 2020) illustrates that many Swedes are very proud of Sweden and the so-called Swedish model; they believe in a unique Swedish national identity, built on a decentralized system and on trust. In the same vein, Simon $(2020,54)$ summarizes his analysis of critical international media reporting on the 'Swedish way' that 'Sweden attempted to leverage its relatively popular and positive global brand (before COVID-19) with a value and normative based frame that was intended to enhance the national image of the country and people as capable and courageous norm entrepreneurs by making use of the crisis of information as an opportunity'. Indeed, as 
politicians repeatedly stated, the Swedish strategy of containing the virus was based on a model of trust and collaboration:

[Our strategy] is built upon information and providing the population with knowledge [...], the success factors of our disease prevention is built on trust and faith [...]. We also strived from the start to have a society that is as open as possible. ${ }^{11}$

This implied that the people were receptive to information and instruction, that depending on interpersonal trust, the best way to have a feasible action plan was if people willingly submit themselves to a kind of 'auto-isolation', in contrast to an enforced one. People are not ordered, they are politely advised to be considerate and to keep their distance.

Everybody's own responsibility is invoked, everybody should help build a mutual relationship of trust. The aim of this 'Swedish trust' was, as Bergenfalk $(2020,33)$ argues, to establish a quasi-symbiotic relationship between the citizens and the authorities that benefitted both parties (legitimization qua moralization). This is consistent with the fact that Swedes generally have a high level of trust in institutions. Therefore, the strategy adopted by the Swedish government not only presupposed an open society with mutual trust between all the nation's citizens, it also aimed to guide society and identity further in this direction. Thus, the strategy, it was presupposed, would produce citizens capable of implementing and practicing a 'regulated freedom' (Bergenfalk 2020, 33).

This finding is substantiated by Pierre $(2020,482)$, who maintains that 'Sweden is a high-trust society, both in terms of interpersonal and institutional trust. This high level of trust facilitates informal yet efficient coordination with very low transaction costs.' The law is thus implemented to the smallest degree possible. For example, Prime Minister Stefan Löfven described new strict regulations at a press conference on 27 March 2020 in the following way:

We will never be able to regulate everything by law, we will never be able to prohibit all deleterious behavior. Instead, it is now a matter of common sense [folkvett]. There is an individual responsibility and each individual must take responsibility for themselves, their peers, and their country. (Overgaard 2020)

An official website (in many languages) was launched that listed all the regulations and provided a lot of information. ${ }^{12}$ Bergenfalk $(2020,40-43)$ concludes that 'death becomes normalized, as we can see throughout the Swedish state's response to the covid-19 pandemic, when the benefits of prosperous life for the many outweigh the suffering of the few'. Thus, death was not denied; ${ }^{13}$ the old and fragile were - so to speak - sacrificed for the 'the welfare, happiness and general health of the majority' (ibid). This implies a quasi-

\footnotetext{
11 Johan Carlson, 2 March 2020, “Vi tror att vår strategi är framgångsrik i det här läget. Den bygger på information och kunnande till befolkningen. [...] framgångsfaktorn i smittskyddsarbetet är att det bygger på tillit och förtroende. [...] Vi har också från början strävat efter att så mycket som möjligt att ett öppet samhälle."

${ }^{12}$ The Public Health Agency of Sweden (2020) also launched a multilingual official website, which was updated almost daily, with a lot of accessible and transparent information.

${ }^{13}$ In hindsight, the state epidemiologist Tegnell acknowledged in an interview with Radio Sweden on 2 June 2020 that "if we were to encounter the same disease, with the knowledge we have today, we would probably have to implement a strategy about halfway between what Sweden did and what the rest of the world did" (Radio Sweden 2020).
} 
rational cost-benefit biopolitics (legitimation qua rationalization) which stands in huge contrast to the decision-making in other countries, where the restrictions were mostly legitimized due to different values; i.e. as a means to protect and save the elderly.

\subsection{The 'War against the Virus'}

Most politicians used war metaphors at some point during the COVID crisis. However, some presidents and prime ministers relied on a conceptual metaphor of 'fighting the virus' or 'the war against the virus' to frame all their public speeches, interviews, and press conferences (legitimation qua authorization). The positive outcome of such a war would be, so the argument went, a 'victory over the virus' by successfully 'defending' the respective country. This discourse was launched by the French President Emanuel Macron on the one hand and by the Hungarian Prime Minister, Viktor Orbán, on the other.

Macron justified the strict measures imposed in France by repeatedly claiming that a war had to be fought; that France was at war. He also appealed to national unity across all party lines.

We are at war and, faced with what is coming, the peak of the epidemic which is before us, I have decided, on the basis of a proposal from the Minister of the Armed Forces and the Chief of the Defense Staff, to launch Operation Resilience.

(Macron 2020)

One month later, Macron had dropped greatly in popularity because of the high death rate, overcrowded hospitals, and a shortage of nurses and doctors. Accordingly, he changed his strategy, now appealing to solidarity and equality, while referring to the French Revolution and quoting the first article of the Human Rights Declaration from 26 August 1789 (legitimation qua rationalization and mythopoesis). More specifically, he promised higher salaries for nurses, care workers, cashiers, and bus drivers. He spoke of hope if the strict measures were followed and even admitted that the government had reacted too slowly at the outset of the fight against the virus.

The strategies adopted by Orbán were significantly different than Macron's. On the one hand, the Hungarian prime minister also viewed the crisis as a 'war against the virus' to be fought and won. Thus, he aimed to fight panic and fear and to defeat the dread of death. However, on the other hand, he also instrumentalized this conceptual mindset to undermine Hungarian democracy.

Viktor Orbán decided to give regular statements via TV and radio in which he continuously used military jargon, thus creating a very different semantic field than the other leaders mentioned above. For example, on 23 March 2020, he described the military operations put in place to defend the Hungarian population (my emphasis):

It was a question of waiting or acting and we decided to take up the fight instead of waiting. We immediately saw that in the usual order, in addition to our usual way of life, upholding our principles of life organization, within the framework of the usual legislation, we would not be able to organize Hungary's collective self-defense, and we would not be able to repel this attack. That is why we [...] declared a state of emergency. The state of emergency 
means that the government has been given the authority and the means to organize Hungary's self-defense with a chance of success. [...]

We have organized the defense along four lines. We have to stand on four battlefields right now. There is a military defense, a police defense, a health defense, and an economic defense. We also knew that there would be three stages in the spread of the virus, so we also need to adjust the pace of defense, what to do, and the decisions and steps to take. (Orbán 2020)

Here, Orbán already mentioned the necessity of implementing a state of emergency in Hungary. On 30 March 2020, The Hungarian Parliament voted to allow Orbán to rule by decree indefinitely (with 138 votes in favor and 53 votes against) in order to combat the pandemic, thus giving Orbán extra powers to unilaterally enact a series of sweeping measures. As CNN reported: 'Its [the parliament's] provisions go well beyond the various forms of legislation hastily put together by other EU member states in response to the coronavirus pandemic, dramatically ramping up the strongman leader's powers' (Picheta \& Halasz 2020). Thus, punishment became possible for journalists if the government believed their coronavirus reporting was not accurate. Moreover, heavier penalties for violating quarantine regulations were made possible by this law. Third, no elections or referendums could be held while this order was in place. Orbán justified this extraordinary measure with the topos of urgency, according to CNN: 'We cannot react quickly if there are debates and lengthy legislative and law-making procedures. And in times of crisis and epidemic, the ability to respond rapidly can save lives' (Picheta \& Halasz 2020).

On 16 June 2020, the state of emergency was lifted. However, as the Friedrich Naumann Foundation rightly argues, 'at the same time as the emergency was lifted, parliament also voted in favor of a draft law on a new, so-called 'state of medical emergency'. According to this bill, the government would be able to govern by decree again in such a case, with even less control than before' (FNFEUROPE 2020). Both bills were adopted by Parliament on 16 June 2020. Meanwhile, debates and discussions have continued on the highest level of EU law-making, in the European Commission, the European Parliament (2019), and the European Court of Human Rights (see Grabbe and Lehne 2019; Wodak 2021). Orbán is thus continuing his path towards illiberalism and neo-authoritarianism, facilitated by the COVID crisis, which he has been able to instrumentalize for his interests.

6. Conclusion: Lessons for the Future?

Historian Reinhart Koselleck notes that we at least know for certain that the uncertainty caused by crises will always come to an end:

It is in the nature of a crisis that a decision is due but not yet taken. The general uncertainty in a critical situation is thus pervaded by the certainty that - uncertain when, but certain, uncertain how, but certain - an end to the critical state is imminent. $(1973,105)$. 
But - we could add here - what happens if crises do not end? Or if one crisis leads to or flows into another, as is the case with which we are currently confronted, as the COVID-19 crisis will obviously lead to a social and economic crisis?

Other theorists, such as the anthropologist Viktor Turner (1987), perceive positive moments within crisis situations, which he calls 'liminality', a state 'betwixt and between': In crises, one is forced to question and challenge the given. Thereby, possibilities for change become visible, borders can be crossed, one can move between old, already broken and violated, and new, not yet consolidated structures. Of course, every crisis is different, affects different areas, and fuels different fears and uncertainties.

On the one hand, many commentators emphasized the positive side of 'deceleration', of slowing down, of finally having time to reflect on one's everyday life, one's wellbeing, one's work-life balance, and so forth. Many reported that they finally had time to reorganize their apartments or houses, clean up their messy cupboards, and tend to their gardens - all strategies deemed successful to cope with the dread of death. On the other hand, such deceleration and reflection lent itself only to the privileged classes, not to workers in the socalled 'critical jobs' (such as cashiers in supermarkets, nurses, builders, police officers, pharmacists, caregivers for the elderly, and so forth) or unemployed people yearning for a new job (Schmidinger and Weidenholzer 2020).

Many threat scenarios failed to materialize. The four frames discussed in this paper resurrection, dialogue, trust, and war - illustrate significantly different ways of coping with the dread of death and emerging fears and anxieties. These frames also point to differing regimes of bio- and body politics, legitimized in significantly different ways: the nation conceptualized as family, with a quasi-Messiah as leader (religious frame, legitimation qua moralization and authorization). We also encountered leaders who talked to their people on an equal level, i.e. establishing a rational dialogue and unifying relationship, full of empathy, with the citizens, employing legitimization via authority and rationalization. The framing with trust implies self-responsibility and no hierarchical leadership (legitimation qua rationalization and moralization) and, finally, 'fighting a war' implies emergency situations where leaders carry the entire responsibility and the people have to follow orders (legitimization qua authority and mythopoesis).

In December 2020, several heads of states and prominent politicians were vaccinated immediately after the vaccines had been approved by the EU Commission and other health agencies (in the US, Israel, and so forth). This was broadcast widely to counter conspiracy theories disseminated by opponents of vaccination (see Euronews with AP 2020). Russia publicized its vaccine 'Sputnik 5' already in August 2020 although it had only been tested with small groups of people (Rainsford 2020). China also developed several vaccines which have not undergone enough standardized trials (Tan 2020). In spite of such rapid success stories, many factors related both to the illness and to its treatment remain unknown; for example: for how long does the protection due to vaccination last? (VFA 2020). Can vaccinated people continue to spread the virus? (McNamara 2020). And so forth and so on. 
It is obvious that there is no 'one size fits all' pattern of crisis communication: Which kind of crisis communication was chosen largely depends - apart from the personality of the respective leader and the kind of government regime - on contextual factors, on individual countries' histories, their collective memories and traumas and national traditions of governmental rhetoric. What works in one country might not work elsewhere. In any case, defeating the virus and the pandemic in general implies confronting (and not denying) facts, defeating the illness and thus, the fear of death. However, as Camus $(1948,277)$ legitimately argued, the plague (or any disease) can never be truly defeated:

None the less, he knew that the tale he had to tell could not be one of a final victory. It could be only the record of what had had to be done, and what assuredly would have to be done again in the never-ending fight against terror and its relentless onslaughts, despite their personal afflictions, by all who, while unable to be saints but refusing to bow down to pestilences, strive their utmost to be healers.

\section{References}

Angouri, J. and Wodak, R. (2014) "They became big in the shadow of the crisis": The Greek success story and the rise of the far right', Discourse \& Society, 25(4): 540-65.

Bakhtin, M., (1982) The Dialogic Imagination: Four Essays. University of Texas Press, Austin. Bauman, Z. (2000) Liquid Modernity. Cambridge: Polity.

Bauman, Z. (2006) Liquid Fear. Cambridge: Polity.

BBC News (2020) 'Germany coronavirus: Hundreds arrested in German 'anti-corona' protests', BBC News (Online), 30 August, <https://www.bbc.co.uk/news/world-europe53959552> [Accessed 05 January 2021].

Becker, E. (2020 [1973]) The Denial of Death. Croyden: Souvenir Press

Bergenfalk, J. (2020) 'Coronavirus, Risk, and Responsibility. A Governmental Analysis of Swedish Crisis Management During the Covid-19 Pandemic'. Unpubl. MA Thesis. Lund University.

Billig, M. (1995) Banal Nationalism. London: Sage.

Boin, A., Lodge, M. and Luesink, M. (2020) 'Learning from the COVID-19 crisis: an initial analysis of national responses. Policy Design and Practice 3(3): 189-204.

BR24. (2020) 'Mahnerin Merkel: Einschränkungen eine "demokratische Zumutung"', BR24 (Online), 23 April, <https://www.br.de/nachrichten/deutschland-welt/mahnerin-merkelcorona-eine-demokratische-zumutung, RwzYxbC> [Accessed 05 January 2021].

Braun, M. (2020) 'Die Stunde des Giuseppe Conte', Zeit Online (Online), 14 March, <https://www.zeit.de/politik/ausland/2020-03/guiseppe-conte-coronavirus-italienquarantaene-ansprache?utm_referrer=https\%3A\%2F\%2Fwww.google.hr> [Accessed 05 January 2021]. 
Cicourel, A. V. (1975) Sprache in der sozialen Interaktion. Munich: List.

Corbett, T. (2020) “"Liebe Österreicherinnen, liebe Österreicher...”. Wie eine Pandemie zur (Re-)-Nationalisierung Europas führt, IWM, Vienna

(https://www.iwm.at/closedbutacitve/corona-focus/tim-corbett-liebe-osterreicherinnenliebe-osterreicher-wie-eine-pandemie-zur-re-nationalisierung-europas-fuhrt/; accessed 15 June 2020).

Crayne, M. P. and Medeiros, K. E. (2020) 'Making Sense of Crisis: Charismatic, Ideological, and Pragmatic Leadership in Response to COVID-19, American Psychologist http://dx.doi.org/10.1037/amp0000715.

De Rycker, A. and Mohd Don, Z. (2013) Discourse and Crisis. Amsterdam: Benjamins.

Diaz, J. (2020) 'U.K. Begins Nationwide Coronavirus Immunization, Largest In Nation's History', NPR (online), 8 December, https://www.npr.org/sections/coronavirus-liveupdates/2020/12/08/944125280/u-k-begins-nationwide-coronavirus-immunization-largestin-nations-history> [Accessed 05 January 2021].

EFE/Reuters (2020) 'Bergamo in Italy: Army called in as funeral services cannot cope with coronavirus victims', DW (Online), 19 March, <https://www.dw.com/en/bergamo-in-italyarmy-called-in-as-funeral-services-cannot-cope-with-coronavirus-victims/a-52838461> [Accessed 05 January 2021].

Entman, R.M. (1993) 'Framing: Toward Clarification of a Fractured Paradigm', Journal of Communication, 43: 51-58. doi:10.1111/i.1460-2466.1993.tb01304.x

Euronews with AP (2020) 'Israeli PM kicks off national vaccination campaign with public jab', Euronews (Online), 20 December, <https://www.euronews.com/2020/12/20/israeli-pmkicks-off-national-vaccination-campaign-with-public-jab> [Accessed 05 January 2021].

European Parliament (2019) 'Parliamentary Questions: Penalties imposed on the Hungarian Government in connection with cohesion policy', European Parliament (Online), 29 June, <https://www.europarl.europa.eu/doceo/document/P-9-2019-002798_EN.html> [Accessed 05 January 2021].

Fillmore, Ch. (1976) Frame Semantics and the Nature of Language. Berkeley: University of California.

Flinders, M. and Wood, M. (2018) 'Discursive depolitisation and political disengagement'. In: Wodak, R. and Forchtner, B. (eds.) Routledge Handbook of Language and Politics. London: Routledge, pp. 618-30.

FNFEurope. (2020) 'Is the State of Emergency in Hungary Really Over?', FNFEurope (Online), 29 June, <https://fnf-europe.org/2020/06/29/is-the-state-of-emergency-in-hungary-reallyover/> [Accessed 05 January 2021].

Gallagher, J. (2020) 'New coronavirus variant: What do we know?', BBC News (Online), 20 December, <https://www.bbc.co.uk/news/health-55388846> [accessed 05 January 2021]. 
Gotsbachner, E. (1999) Identitätspolitik. Ausländerbilder als symbolische Ressource in Schlichtungsverhandlungen. In: Pelikan, Ch. (ed.) Mediationsverfahren. Jahrbuch für Rechtsund Kriminalsoziologie. Baden-Baden: Nomos, pp. 189-239.

Grabbe, H. and Lehne, S. (2019) 'The EU's values crisis: Past and future responses to threats to the rule of law and democratic principles', in Bevelander, P. and Wodak, R. (eds.) Europe at the Crossroads. Lund: Nordic Academic Press, pp. 49-62.

Greenberg, J., Solomon, S. and Pyszczynski, T. (2015) The Worm at the Core: On the Role of Death in Life. New York: Penguin Random House.

Hallengren, L. (2020) 'Speech by Minister for Health and Social Affairs Lena Hallengren at WHO briefing 23 April', Government Offices of Sweden (Online), 29 April, $<$ https://www.government.se/speeches/2020/04/speech-by-minister-for-health-and-socialaffairs-lena-hallengren-at-who-briefing-23-april/> [Accessed 05 January 2021].

Hansson, S. (2015) 'Discursive strategies of blame avoidance in government: A framework for analysis', Discourse \& Society, 26(3): 297-323.

Hattke, F. and Martin, H. (2020) 'Collective Action during the Covid-19 pandemic: The case of Germany's fragmented authority', Administrative Theory and Praxis DOI: 10.1080710841806.2020.1805273.

Helsingen, L. E. et al (2020) 'Trust, threats, and consequences of the COVID-19pandemic in Norway and Sweden - a comparative survey', medRxiv preprint doi: https://doi.org/10.1101/2020.05.16.20089953.

Huang, M. and Holmgreen, L-L. (eds.) (2020) The Language of Crisis. Metaphors, frames and discourses. Amsterdam: Benjamins.

ITV News (2020) 'Italy announces tough new measures as coronavirus death toll spikes', ITV News (Online), 22 March, <https://www.itv.com/news/2020-03-22/italy-announces-toughnew-measures-as-coronavirus-death-toll-spikes $>$ [Accessed 05 January 2021].

Jost, J. T., Stern, C., Rule, N. O., \& Sterling, J. (2017) The politics of fear: Is there an ideological asymmetry in existential motivation? Social Cognition, 35(4): 324-53. https://doi.org/10.1521/soco.2017.35.4.324

Khoo, H. and Schimpfössl, E. (2020) ,Virus im Brexitland', In: Schmidinger, T. and Weidenholzer, J. (eds.) (2020) Virenregime. Wie die Coronakrise unsere Welt verändert. Befunde, Analysen, Anregungen. Vienna: Bahoe books, pp. 153-64.

Koselleck, R. (1973) Kritik und Krise. Frankfurt/Main: Suhrkamp.

Lakoff, G. (2004) Don't Think of an Elephant: Know Your Values and Frame the Debate. White River Junction, VT: Chelsea Green.

Lazar, M. (2020) 'Leaders Revealed by Covid-19: The Curious Giuseppe Conte', Institute Montaigne (Online), 1 September, <https://www.institutmontaigne.org/en/blog/leadersrevealed-covid-19-curious-giuseppe-conte> [Accessed 05 January 2021]. 
Lehner, S. and Wodak, R. (2020) 'Nationalismus und Populismus', in De Cillia, R., Wodak, R., Rheindorf, M. and Lehner, S. (eds.) Österreichische Identitäten im Wandel. Berlin: Springer, pp. 169-204.

Macron, E. (2020) 'Déclaration de M. Emmanuel Macron, président de la République, sur la mobilisation face à l'épidémie de Covid-19, en particulier le rôle des soignants, et sur le lancement de l'opération militaire Résilience en soutien à lutte contre la diffusion du coronavirus, Mulhouse, le 25 mars 2020', Vie Publique (Online), 25 March, <https://www.viepublique.fr/discours/273982-emmanuel-macron-25-mars-2020-discours-de-mulhouse> [Accessed 05 January 2021].

Maragakis, L. L. (2020) 'Coronavirus Second Wave? Why Cases Increase', Johns Hopkins Medicine (Online), 17 November, <https://www.hopkinsmedicine.org/health/conditionsand-diseases/coronavirus/first-and-second-waves-of-coronavirus> [Accessed 05 January 2021].

Marin, B. (2020) 'Welfare in Post-Quarantimes: Life and Work after the Corona-Camp'. Institute for Human Sciences, Vienna (unpubl. ms.)

McNamara, A. (2020) 'Could people still be infectious after they're vaccinated for COVID-19?', CBS News (Online), 11 December, <https://www.cbsnews.com/news/covid-19-vaccineinfectious/> [Accessed 05 January 2021].

Merkel, A. (2020) 'Pressekonferenz von Bundeskanzlerin Dr. Angela Merkel anlässlich der Besprechung mit den Regierungschefinnen und Regierungschefs der Länder zum Coronavirus', bundesregierung.de (Online), 22 March, <https://www.bundesregierung.de/resource/blob/992798/1733226/d1abd72b7073991584 d48db842f4b0f3/2020-03-22-streaming-merkel-bundeslaender-gebaerdenspracheausschriftung-data.pdf?download=1> [Accessed 05 January 2021].

Merkur.de (2020) 'Wegen Corona-Krise: Hängt Merkel noch eine Amtszeit dran? Umfrage zeigt bereits Zustimmung', Merkur.de (Online), 18 May, $<$ https://www.merkur.de/politik/coronavirus-deutschland-angela-merkel-kanzler-soedermerz-laschet-roettgen-kanzlerschaft-news-zr-13639261.html> [Accessed 05 January 2021].

Mitsotakis, K. (2020) 'Message of the Prime Minister Kyriakos Mitsotakis to the citizens', Office of the Prime Minister (Online), 13 April, <https://primeminister.gr/2020/04/13/23747> [Accessed 05 January 2021].

Musolff, A. (2010) Metaphor, Nation, and the Holocaust. London: Routledge.

Neüff, M. (2018) Words of Crisis as Words of Power. Amsterdam: Benjamins.

Novy, A. and Winckler, C.R. (2020) 'Covid-19 in Brasilien' In Schmidinger, T. and Weidenholzer, J. (eds.) (2020) Virenregime. Wie die Coronakrise unsere Welt verändert. Befunde, Analysen, Anregungen. Vienna: Bahoe books, pp. 218-229. 
Orbán, V. (2020) 'Orbán Viktor sajtónyilatkozata az operatív törzs ülését követően', miniszterelnok.hu (Online), 23 March, <http://www.miniszterelnok.hu/orban-viktorsajtonyilatkozata-az-operativ-torzs-uleset-kovetoen/> [Accessed 05 January 2021].

Overgaard, S. (2020) 'Sweden Bans Groups Larger Than 50 In Its First Major Coronavirus Crackdown', NPR (Online), 27 March, <https://www.npr.org/sections/coronavirus-liveupdates/2020/03/27/822463152/sweden-bans-groups-larger-than-50-in-its-first-majorcoronavirus-crackdown?t=1602070770378> [Accessed 05 January 2021].

Pankl, G. (2020) 'Bernd Marin in dialogue with Georg Pankl: Post-Quarantimes: Ways out of the "Corona Camp"', IWM (Online), 29 April, <https://www.iwm.at/always-active/coronafocus/bernd-marin-im-dialog-mit-georg-panklpost-quarantimes-wege-aus-dem-coronacamp/?utm_source=mailpoet\&utm_medium=email\&utm_campaign=iwm-events-feminismand-inequality-in-europe_72> [Accessed 05 January 2021].

Picheta, R. and Halasz, S. (2020) 'Hungarian parliament votes to let Viktor Orbán rule by decree in wake of coronavirus pandemic', CNN (Online), 30 March, $<$ https://edition.cnn.com/2020/03/30/europe/hungary-viktor-orban-powers-voteintl/index.html> [Accessed 05 January 2021].

Pierre, J. (2020) 'Nudges against pandemics: Sweden's COVID-19 containment strategy in perspective', Policy and Society, 39(3): 478-493, DOI: 10.1080/14494035.2020.1783787.

Powers, J.H. and Xiao, X. (eds.) (2008) The Social Construction of SARS. Amsterdam: Benjamins.

Public Health Agency of Sweden (2020) 'COVID-19', Public Health Agency of Sweden (Online), 21 December, <https://www.folkhalsomyndigheten.se/the-public-health-agencyof-sweden/communicable-disease-control/covid-19/ > [Accessed 05 January 2021].

Pyszczynski, T. (2004) 'What Are We So Afraid Of? A Terror Management Theory Perspective on the Politics of Fear', social research 71(4): 827-848.

Pyszczynski, T., Lockett , M., Greenberg, J. and Solomon, S. (2020) 'Terror Management Theory and the COVID-19', Pandemic Journal of Humanistic Psychology https://doi.org/10.1177/0022167820959488

Radio Sweden (2020) 'Anders Tegnell: My comments were overinterpreted', Radio Sweden (Online), 3 June, <https://sverigesradio.se/artikel/7487961> [Accessed 05 January 2021].

Rainsford, S. (2020) 'Coronavirus: Sputnik V vaccine rushed out to wary Russians', BBC News (Online), 8 December, <https://www.bbc.co.uk/news/world-europe-55221785> [Accessed 05 January 2021].

Reisigl, M. and Wodak, R. (2001) Discourse and Discrimination. The Rhetorics of Racism and antisemitism. London: Routledge.

Reisigl, M. and Wodak, R. (2009) The discourse-historical approach (DHA). In: Wodak, R. and Meyer, M. (eds.) Methods of Critical Discourse Analysis. London: Sage, pp. 87-121. 
Rheindorf, M. (2018) 'Disciplining the unwilling. Normalisation of (demands for) punitive measures against immigrants in Austrian populist discourse'. In: Kranert, M. and Horan, G. (eds.), 'Doing Politics': Discursivity, Performativity and Mediation in Political Discourse. London: Benjamins, pp. 179-208.

Rheindorf, M. (2019) Revisiting the Toolbox of discourse studies. Basingstoke: Palgrave.

Rheindorf, M. and Wodak, R. (2018) 'Borders, fences and limits - protecting Austria from refugees: Metadiscursive negotiations of meaning in the current refugee crisis', Journal of Immigrant \& Refugee Studies, 16(1-2): 15-38.

Rheindorf, M. and Wodak, R. (2020) 'Building "Fortress Europe": Legitimizing Exclusion from Basic Human Rights', In: Rheindorf, M. and Wodak, R. (eds.) Sociolinguistic Perspectives on Migration Control. Bristol: Multilingual Matters, pp. 116-141.

Schmidinger, T. and Weidenholzer, J. (eds.) (2020) Virenregime. Wie die Coronakrise unsere Welt verändert. Befunde, Analysen, Anregungen. Vienna: Bahoe books.

Schumann, F. and Simmank, J. (2020) "'Wir haben es selbst in der Hand"', Zeit Online (Online), 8 October, <https://www.zeit.de/wissen/2020-10/christian-drosten-coronamassnahmen-neuinfektionen-herbst-winter-covid-19 > [Accessed 05 January 2021].

Simon, G. (2020) , Swedish Government and Country Image during the International Media Coverage of the Coronavirus Pandemic Strategy: From Bold to Pariah', Journalism \& Media 1: 41-58.

Spring, M. \& Wendling, M. (2020) 'How Covid-19 myths are merging with the QAnon conspiracy theory', BBC News (Online), 2 September, <https://www.bbc.co.uk/news/blogstrending-53997203> [Accessed 05 January 2021].

Statista (2021) 'Entwicklung der Coronavirus-Epidemie (COVID-19) im Bundesland Tirol Februar 2020"', Statista (Online), 3 January, $<$ https://de.statista.com/statistik/daten/studie/1114903/umfrage/entwicklung-derfallzahlen-des-coronavirus-in-tirol/\#professional> [Accessed 05 January 2021].

Stern, V. (2020) 'Die USA in Zeiten von Corona' In: Schmidinger, T. and Weidenholzer, J. (eds.) (2020) Virenregime. Wie die Coronakrise unsere Welt verändert. Befunde, Analysen, Anregungen. Vienna: Bahoe books, pp. 182-187.

Stråth, B. and Wodak, R. (2009) 'Europe - discourse - politics - media - history: Constructing crises?', in Triandafyllidou, A., Wodak, R. and Krzyżanowski, M. (eds), Europe in Crisis: The 'European Public Sphere' and National Media in the Post-War Period. Basingstoke: Palgrave, pp. 15-33.

Tan, Y. (2020) 'Covid: What do we know about China's coronavirus vaccines?', BBC News (Online), 30 December, <https://www.bbc.co.uk/news/world-asia-china-55212787> [Accessed 05 January 2021].

The Lancet (2020) 'COVID-19: learning from experience', The Lancet, 395(10229), 1011. https://doi.org/10.1016/S0140-6736(20)30686-3 
Triandafyllidou, A., Wodak, R. and Krzyżanowski, M. (eds.) (2009) Europe in Crisis: The 'European Public Sphere' and National Media in the Post-War Period. Basingstoke: Palgrave.

Turner, V. (1987) "Betwixt and Between: The Liminal Period in Rites of Passage", In: Mahdi, L. C., Foster. S. and Little, M. (eds.) Betwixt and Between: Patterns of Masculine and Feminine Initiation Peru, III.: Open Court, pp. 3-22.

van Dijk, T.A. (1991) News as Discourse. New York: Erlbaum.

Van Dijk, T. A. (1992) 'Discourse and the denial of racism', Discourse \& Society, 3(1): 87-118.

Van Dijk, T.A. (2020) Critical Review of Framing Studies in Social Movement Research.

Barcelona: Centre of Discourse Studies (unpubl. paper).

Van Leeuwen, T. and Wodak, R. (1999) 'Legitimizing immigration control: A discoursehistorical analysis', Discourse Studies, 1(1): 83-118.

VFA. (2020) 'Vaccines to protect against Covid-19, the new coronavirus infection', VFA (Online), 2 December, <https://www.vfa.de/de/englische-inhalte/vaccines-to-protectagainst-covid-19> [Accessed 05 January 2021].

Vienna.at (2020) 'Kurz: "Coronavirus wird uns noch monatelang begleiten"', Vienna.at (Online), 11 April, <https://www.vienna.at/kurz-coronavirus-wird-uns-noch-monatelangbegleiten/6585613> [Accessed 05 January 2021].

WHO (2020) 'Coronavirus disease (COVID-19) pandemic', WHO, <https://www.who.int/emergencies/diseases/novel-coronavirus-2019> [Accessed 05 January 2021].

WKO (2021) 'Coronavirus: Situation in Griechenland', WKO, $<$ https://www.wko.at/service/aussenwirtschaft/coronavirus:-situation-ingriechenland.html> [Accessed 05 January 2021].

Wodak, R. (2018) "Strangers in Europe": A discourse-historical approach to the legitimation of immigration control 2015/16', in Zhao, S. et al. (eds.), Advancing Multimodal and Critical Discourse Studies. London: Routledge, pp. 31-50.

Wodak, R. (2019a) 'Entering the "post-shame era" - the rise of illiberal democracy, populism and neo-authoritarianism in EU-rope: The case of the turquoise-blue government in Austria 2017/2018', Global Discourse. doi: 10.1332/204378919X15470487645420.

Wodak, R. (2019b) "'We have the character of an island nation": A discourse-historical analysis of David Cameron's "Bloomberg Speech" on the European Union', in Kranert, M. and Horan, G. (eds.), 'Doing Politics': Discursivity, Performativity and Mediation in Political Discourse. London: Benjamins, pp. 27-58.

Wodak, R. (2020a) 'Analysing the politics of denial: critical discourse studies and the discourse-historical approach', in Krippendorf, K. and Halabi, N. (eds.) Discourses in Action. What language enables us to do. London: Routledge, pp. 19-36. 
Wodak, R. (2020b) "“Wir haben alles richtig gemacht!" - Krisenkommunikation und Krisenmanagement in "Corona-Zeiten “', in Schmidinger, T. and Weidenholzer, J. (eds.) Virenregime. Wie die Coronakrise unsere Welt verändert. Befunde, Analysen, Anregungen. Vienna: Bahoe books, pp. 330-341.

Wodak, R. (2020c) 'Normalization to the right: Analyzing the micro-politics of the far right', In: Ashe, S.D., Busher, J., Macklin, G. and Winter, A. (eds.) Researching the Far Right: Theory, Method and Practice. London: Routledge.

Wodak, R. (2021) The Politics of Fear. The Shameless Normalization of far-right populist discourses. London: Sage ( $2^{\text {nd }}$ revised and extended edition). 